\title{
Peningkatan Minat dan Hasil Belajar Matematika melalui Model Cooperative Learning Tipe Team Games Tournament pada Siswa SD Negeri Tukangan Yogyakarta
}

\author{
Achmad Nur Sodiq ${ }^{* 1}$, Trisniawati ${ }^{2}$ \\ ${ }^{1,2}$ Program Studi Pendidikan Guru Sekolah Dasar, Universitas Sarjanawiyata Tamansiswa \\ *ahmadnurulshodiq01@gmail.com, trisniawati.87@gmail.com
}

\begin{abstract}
ABSTRAK
Tujuan penelitian adalah untuk mendeskripsikan peningkatan minat dan hasil belajar matematika siswa kelas II SD Negeri Tukangan Yogyakarta. Jenis penelitian ini adalah penelitian tindakan kelas. Subjek penelitian ini adalah siswa kelas II SD Negeri Tukangan dengan jumlah siswa 20 orang yang terdiri dari 12 siswa laki-laki dan 8 siswa perempuan. Analisis data menggunakan analisis deskriptif dan analisis kuantitatif untuk mengetahui persentase peningkatakan minat dan hasil belajar matematika. Hasil penelitian menunjukkan bahwa model cooperative learning tipe Team Games Tournament (TGT) dapat meningkatkan minat dan hasil belajar matematika siswa kelas II dalam pembelajaran matematika di SDN Tukangan Yogyakarta. Rata-rata persentase minat siswa setiap aspek pada pratindakan sebesar 57,7\% dengan kualifikasi rendah, meningkat pada siklus I menjadi $72,2 \%$ dengan kualifikasi sedang. Pada siklus II kembali mengalami peningkatan menjadi $80,2 \%$ dengan kualifikasi tinggi. Rata-rata hasil belajar matematika pada pratindakan 66,48 dengan ketuntasan belajar $30 \%$, meningkat menjadi 71,41 pada siklus I dengan ketuntasan belajar $70 \%$ dan pada siklus II mengalami peningkatan dengan nilai rerata 79,72 dengan ketuntasan belajar $80 \%$.
\end{abstract}

Kata kunci: hasil belajar, minat, team games tournament.

\begin{abstract}
The purpose of the study was to describe the increased interest and learning outcomes of students in grade II at SD Negeri Tukangan Yogyakarta. This type of research is classroom action research. The subjects of this study were the second grade students of SD Negeri Tukangan with 20 students consisting of 12 male students and 8 female students. Data analysis using descriptive analysis and quantitative analysis to determine the percentage increase in interest and learning outcomes in mathematics. The results showed that the cooperative learning model Team Games Tournament (TGT) type could increase interest and learning outcomes of students in grade II mathematics learning in mathematics at SDN Tukangan Yogyakarta. The average percentage of student interest in each aspect of the pre-cycle was $57.7 \%$ with low qualifications, increasing in the cycle I to $72.2 \%$ with medium qualifications. In cycle II it again increased to $80.2 \%$ with high qualifications. The average mathematics learning outcomes in the pre-cycle 66.48 with $30 \%$ mastery learning, increased to 71.41 in the cycle I with $70 \%$ mastery learning and in the second cycle has increased with a mean value of 79.72 with $80 \%$ completeness learning.
\end{abstract}

Key words: interests, learning outcomes, team games tournament.

\section{Pendahuluan}

Matematika merupakan salah satu mata pelajaran yang penting karena mata pelajaran matematika mendukung mata pelajaran lainnya. Matematika merupakan salah satu disiplin ilmu yang dapat meningkatkan kemampuan berpikir dan berargumentasi, memberikan kontribusi dalam penyelesaian masalah sehari-hari dan dalam dunia kerja, serta memberikan dukungan dalam pengembangan ilmu pengetahuan dan teknologi (Susanto, 2013). Dalam dunia pendidikan, metematika telah diperkenalkan kepada siswa sejak tingkat dasar sampai ke jenjang yang lebih tinggi. Pada pendidikan matematika, pendidik mempunyai peranan penting dalam mewujudkan tercapainya tujuan pembelajaran. Tujuan pembelajaran matematika di sekolah bukan hanya membentuk siswa terampil dalam menggunakan matematika, tetapi juga terampil pada aspek kognitif, afektif dan psikomotor. Namun banyak siswa mengalami 
kesulitan dalam mempelajari matematika. Salah satu penyebab kesulitan tersebut adalah objek matematika yang abstrak yang membuat matematika sulit dipahami.

Berdasarkan peraturan menteri pendidikan nasional nomor 22 tahun 2006 tentang standar isi, pembelajaran matematika tingkat SD/MI memiliki tujuan agar peserta didik memiliki kemampuan berikut ini.

1. Memahami konsep matematika, menjelaskan keterkaitan antarkonsep dan mengaplikasikan konsep atau algoritma, secara luwes, akurat, efisien, dan tepat, dalam pemecahan masalah.

2. Menggunakan penalaran pada pola dan sifat, melakukan manipulasi matematika dalam membuat generalisasi, menyusun bukti, atau menjelaskan gagasan dan pernyataan matematika.

3. Memecahkan masalah yang meliputi kemampuan memahami masalah, merancang model matematika, menyelesaikan model dan menafsirkan solusi yang diperoleh.

4. Mengomunikasikan gagasan dengan simbol, tabel, diagram, atau media lain untuk memperjelas keadaan atau masalah.

5. Memiliki sikap menghargai kegunaan matematika dalam kehidupan, yaitu memiliki rasa ingin tahu, perhatian, dan minat dalam mempelajari matematika, serta sikap ulet dan percaya diri dalam pemecahan masalah.

Berdasarkan hasil observasi, ketika guru memberikan pertanyaan banyak siswa yang tidak menjawab, selain itu juga dapat dilihat ketika dalam pembelajaran di dalam kelas banyak siswa yang kurang antusias, ketika mengerjakan soal juga tidak berdiskusi dan cenderung lama mengerjakan. Pembelajaran yang dilaksanakan menggunakan metode ceramah, sehingga minat siswa terhadap matematika rendah. Padahal minat adalah salah satu faktor yang mempengaruhi keefektifan kegiatan belajar siswa dan yang mendorong siswa untuk melakukan kegiatan belajar (Baharudin \& Wahyuni, 2010). Minat merupakan suatu perasaan atas pilihan terhadap kegiatan, cita-cita, atau objek tertentu (Aiken, 1999). Minat memiliki karateristik pokok, yaitu melakukan suatu kegiatan yang dipilih sendiri dan menyenangkan sehingga dapat membentuk suatu kebiasaan dalam diri seseorang. Minat dalam pembelajaran matematika dapat diartikan sebagai kesenangan dan ketertarikan untuk memahami matematika lebih dalam dan kebiasaan untuk belajar matematika. Selanjutnya menurut Djamarah (2002) menyebutkan "Minat belajar cenderung menghasilkan prestasi yang tinggi, sebaliknya minat belajar yang kurang akan menghasilkan prestasi belajar yang rendah". Minat yang besar terhadap sesuatu merupakan modal yang besar artinya untuk mencapai atau memperoleh benda atau tujuan yang diminati itu.

Lebih lanjut menurut (Brookhart, 2007) minat merupakan pilihan bentuk-bentuk tertentu dari suatu aktivitas ketika seseorang tidak sedang berada dalam tekanan dari luar dirinya. Minat berhubungan dengan keingintahuan, minat merupakan suatu sifat abadi yang ditunjukkan dengan suatu hubungan antara seseorang dengan aktivitas atau objek tertentu (Taylor et al., 2001). Menurut (Sax, 1980) menyatakan bahwa minat merupakan pilihan terhadap satu kegiatan dibandingkan dengan yang lainnya. Pengertian ini menekankan pada dua hal. Pertama, minat melibatkan pilihan dan rangking dari kegiatan sepanjang dimensi suka-tidak suka. Kedua, minat melibatkan aktifitas atau perilaku yang digunakan oleh individu.

Sementara itu, Ainley, et al (2002) mengemukakan bahwa secara umum minat individu dalam pembelajaran diekspresikan melalui keinginan memperoleh informasi yang baru, mengetahui tentang seuatu objek, peristiwa, dan ide baru tanpa dibatasi bidang yang sempit. Deci (Elliot et al, 2000) menyatakan bahwa minat muncul ketika kebutuhan, kemampuan, dan 
keterampilan peserta didik sangat sesuai dengan kebutuhan yang ditawarkan oleh aktivitas tertentu. Sementara itu Stipek (Woolfolk, 2007: 384) berpendapat bahwa minat akan meningkat ketika siswa merasa mampu, bahkan jika siswa pada awalnya tidak tertarik pada suatu subjek atau aktifitas, mereka mungkin mengembangkan minat saat mereka memperoleh pengalaman sukses. Lebih lanjut menurut (Rhosyida, Muanifah, \& Trisniawati, 2019), dalam bidang studi matematika, minat seseorang terhadap pelajaran dapat dilihat dari kecenderungan untuk memberikan perhatian yang lebih besar terhadap pelajaran tersebut.

Berdasarkan data hasil observasi yang dilakukan, pembelajaran matematika yang ada di SD Negeri Tukangan Yogyakarta, pembelajaran matematika pada materi perkalian dan pembagian masih menggunakan metode ceramah. Guru menyampaikan materi secara langsung dengan konsep abstrak tanpa melalui pendekatan-pendekatan yang sesuai dengan tahap perkembangan berfikir siswa yang seharusnya mulai dari hal yang sifat konkret ke hal yang bersifat abstrak. Siswa hanya menghafal apa yang disampaikan guru tanpa mengetahui makna dari materi yang disampaikan.

Selain itu, hasil belajar siswa tidak memenuhi Kriteria Ketuntasan Minimal (KKM) yang telah ditentukan sehingga hasil belajar siswa rendah. Apabila hasil belajar siswa rendah maka tujuan pembelajaran belum tercapai. Hasil belajar adalah perubahan tingkah laku pada orang tersebut dari tidak tahu menjadi tahu. Perubahan tingkah laku yang termasuk hasil belajar meliputi beberapa aspek antara lain: pengetahuan, emosional, pengertian, hubungan sosial, kebiasaan, jasmani, keterampilan etis, atau budi pekerti, apresiasi, dan sikap (Arifin, 2012). Dalam hal ini perlu suatu model yang diduga dapat meningkatkan minat dan hasil belajar siswa SD Negeri Tukangan Yogyakarta yaitu dengan model model Cooperative Learning tipe Team Games Tournament (TGT). Menurut (Wilujeng, 2013) pembelajaran kooperatif tipe TGT adalah salah satu tipe atau model pembelajaran kooperatif yang mudah diterapkan, melibatkan seluruh siswa tanpa harus ada perbedaan status. Tipe ini melibatkan peran siswa sebagai tutor sebaya, mengandung unsur permainan yang bisa menggairahkan semangat belajar dan mengandung penguatan. Lebih lanjut (Hadi, 2017) mengemukakan model pembelajaran $T G T$ salah satu alternatif yang dapat digunakan guru, karena model pembelajaran ini sesuai dengan karakter siswa yang senang dengan permainan dan pertandingan.

Menurut (Slavin, 2006) mendefinisikan kooperatif sebagai sebagai metode untuk mengemukakan ide dengan bekerja sama dalam kelompok dan bertanggung jawab terhadap kelompok belajar mereka. Salah satu model pembelajaran yang melibatkan peran siswa secara aktif adalah model Cooperative Learning tipe Team Games Tournament (TGT). Model pembelajaran kooperatif (cooperative learning) diyakini sebagai praktik pedagogis untuk meningkatkan proses pembelajaran, gaya berpikir tingkat-tinggi, perilaku sosial, sekaligus kepedulian terhadap siswa-siswa yang memiliki latar belakang kemampuan, penyesuaian, dan kebutuhan yang berbeda-beda (Huda, 2016). Dengan menggunakan model pembelajaran TGT siswa akan mempunyai kebebasan untuk berdiskusi dan saling memberikan informasi untuk memahami satu konsep matematika. Siswa saling bekerja sama antar anggota kelommpok untuk menyelesaikan masalah yang diberikan. Anggota kelompok TGT yang heterogen dapat memberikan peluang kepada siswa yang berkemampuan rendah untuk dapat meningkatkan kemampuan bersama siswa lain yang berkemampuan tinggi. Dengan menggunakan model cooperative learning tipe Team Games Tournament (TGT) inilah diharapkan minat dan hasil belajar siswa dalam pembelajaran matematika meningkat.

70 | $\begin{aligned} & \text { C2020 by Department of Mathematics Education, UMP, Purwokerto, Indonesia } \\ & \text { p-ISSN 2477-409X, e-ISSN: 2549-9084 and website: http://jurnal nasional.ump.ac.id/index.php/alphamath/ }\end{aligned}$ 
Adapun langkah-langkah pembelajaran dengan model pembelajaran kooperatif tipe $T G T$ yaitu (1) Mengelompokan siswa menjadi sejumlah tim yang beranggotakan 3 hingga 5 siswa, setiap kelompok mempunyai jumlah anggota yang sama; (2) Memberikan materi kepada tim untuk dipelajari bersama dan embuat beberapa pertanyaan yang menguji pemahaman atau pengingatan akan materi pelajaran, format pertanyaan hendaknya mudah untuk penilaian sendiri misaalnya pilihan ganda, mengisi titik-titik, benar/salah, (3) Memberikan sebagian pertanyaan kepada siswa, sebutlah ini sebagai "ronde satu", setiap siswa harus menjawab pertanyaan secara perorangan, etelah pertanyaan diajukan, sediakan jawabannya dan siswa diminta untuk menghitung jumlah jawaban yang benar, selanjutnya siswa diminta untuk menyatukan skor mereka dengan tiap anggota tim mereka untuk mendapatkan skor tim, kemudian umumkan skor dari tiap tim.; (4) Selanjutnya siswa diminta belajar lagi untuk "ronde kedua" kemudian diajukan pertanyaan atau tes lagi sebagai bagian dari ronde kedua tersebut, lamanya metode ini dapat bervariasi, dan ronde yang digunakan bisa sebanyak mungkin, pastikan untuk memberi kesempatan pada tim untuk menjalani sesi belajar antar masing-masing ronde. Berdasarkan uraian tersebut, maka tujuan penelitian ini adalah mendeskripsikan peningkatan minat dan hasil belajar matematika melalui model cooperative learning tipe Team Games Tournament (TGT) pada siswa SD Negeri Tukangan Yogyakarta.

\section{Metode Penelitian}

Penelitian ini merupakan penelitian tindakan kelas dengan model Suharsimi Arikunto. Menurut Arikunto (2013) penelitian tindakan kelas merupakan suatu pencermatan terhadap kegiatan belajar berupa sebuah tindakan, yang sengaja dimunculkan dan terjadi dalam sebuah kelas secara bersama, dan dilaksanakan minimal dalam dua siklus. Setiap siklus dilakukan dengan empat tahap yaitu: perencanaan (planing), tindakan (acting), pengamatan (observing), dan refleksi (reflecting). Subjek dalam penelitian ini adalah siswa kelas II SD Negeri Tukangan dengan jumlah siswa 20 orang yang terdiri dari 12 siswa laki-laki dan 8 siswa perempuan.

Instrumen penelitian ini berbentuk lembar observasi minat dan soal pilihan ganda. Teknik pengumpulan data yang digunakan dalam penelitian ini adalah dengan teknik observasi, teknik daftar cek, teknik tes, dan teknik dokumentasi.. Teknik analisis data dalam penelitian ini yaitu deskriptif kualitatif pada lembar observasi minat. Sedangkan untuk menganalisis data berupa hasil tes belajar siswa menggunakan teknik deskriptif kuantitatif. Indikator keberhasilan dalam penelitian ini yaitu apabila peningkatan minat belajar dengan kategori tinggi dengan persentase di atas $75 \%$ dan apabila peningkatan hasil belajar siswa dari satu siklus ke siklus selanjutnya dan minimal $75 \%$ dari seluruh jumlah siswa mampu mencapai KKM yang sudah ditentukan yaitu 75 .

\section{Hasil dan Pembahasan \\ Hasil}

Penelitian ini dilaksanakan di kelas II SD Negeri Tukangan Yogyakarta sebanyak 20 orang siswa dengan menggunakan model cooperative learning tipe team games tournament. Penelitian ini dilaksanakan dua siklus dan didahului dengan pra siklus. Pada prasiklus data yang digunakan adalah hasil data observasi minat dan rata-rata hasil nilai ulangan siswa kelas II SD Negeri Tukangan Yogyakarta. Sedangkan untuk siklus I dan II menggunakan hasil data observasi minat dan rata-rata hasil nilai tes siklus I dan II yang berbentuk pilihan ganda. Aspek minat belajar yang diukur terdiri dari aspek perasaan senang, ketertarikan, keterlibatan siswa, dan perhatian siswa. Berikut ini deskripsi hasil minat belajar siswa pada setiap siklus: 
Tabel 1. Deskripsi hasil minat belajar siswa pada tiap siklus

\begin{tabular}{lccc}
\hline \multicolumn{1}{c}{ Aspek } & \multicolumn{3}{c}{ Persentase } \\
& Prasiklus & Siklus I & Siklus II \\
\hline Perasaan Senang & $55,2 \%$ & $72,7 \%$ & $72,7 \%$ \\
Ketertarikan & $56,6 \%$ & $69,6 \%$ & $80,0 \%$ \\
Keterlibatan Siswa & $59,3 \%$ & $72,7 \%$ & $85,8 \%$ \\
Perhatian Siswa & $58,6 \%$ & $72,3 \%$ & $81,4 \%$ \\
Rata-rata & $57,7 \%$ & $72,2 \%$ & $80,2 \%$ \\
\hline
\end{tabular}

Berikut ini deskripsi data hasil belajar siswa pada tiap siklus.

Tabel 2. Deskripsi data hasil belajar tiap siklus

\begin{tabular}{lccc}
\hline \multicolumn{1}{c}{ Kriteria } & Pratindakan & Tes Siklus I & Tes Siklus II \\
\hline Rata-rata nilai & 66,48 & 71,41 & 79,72 \\
Nilai tertinggi siswa & 75 & 100 & 100 \\
Nilai terendah siswa & 45 & 12 & 22 \\
Jumlah Siswa Tuntas & 6 & 14 & 16 \\
\hline
\end{tabular}

\section{Pembahasan}

Penelitian ini didahului dengan adnya observasi pembelajaran selama magang di SD Negeri Tukangan Yogyakarta. Berdasarkan pengamatan, ketika pembelajaran berlangsung terdapat siswa yang kurang bergairah dalam mengikuti pembelajaran bahkan ada yang bermain dan mengobrol dengan teman sebangkunya. Hal tersebut menggambarkan bahwa minat siswa dalam mengikuti pembelajaran masih rendah. Selain itu ketika dilakukan tes atau evaluasi hasil yang didapatkan siswa masih banyak yang belum memenuhi kriteria ketuntasan minimal (KKM) dapat dikatakan hasil belajarnya masih rendah, sehingga perlu ditingkatkan minat dan hasil belajar matematika siswa.

Pelaksanaan tindakan dalam penelitian ini dilaksanakan dalam dua siklus, dimana setiap siklusnya terdiri dari 2 kali pertemuan. Materi yang diajarkan yaitu bangun datar, meliputi bentuk dan unsur-unsur bangun datar persegi dan persegi panjang. Pembelajaran yang dilakukan menggunakan model pembelajaran Team Games Tournament (TGT) yaitu melalui tahapan penomoran, mengajukan pertanyaan, berpikir bersama dan menjawab. Padaa saat kegiatan pembelajaran dilakukan kegiatan eksplorasi, elaborasi, dan konfirmasi. Pada kegiatan eksplorasi, siswa diberikan sedikit gambaran umum dari materi tentang bentukbentuk bangun datar. Pada kegiatan elaborasi, guru memberikan materi kepada kelompokkelompok yang telah dibentuk dengan memberi nama pada team misal kelompok Dahlia, kelompok Lili, kelompok Mawar, kelompok Kenanga, dan kelompok Melati.

Kegiatan selanjutnya guru memberikan lembar kerja siswa materi tentang bentuk-bentuk bangun datar yang telah disiapkan untuk didiskusikan secara berkelompok dengan guru memfasilitasi diskusi kelompok yang dilakukan siswa. Siswa menyatukan pendapatnya terhadap pertanyaaan itu dan menyakinkan tiap anggota dalam timnya mengetahui jawaban itu. Guru mengecek pemahaman siswa dengan memberikan pertanyaan kepada kelompok dengan cara menyebut salah satu nomor yang dipunyai kelompok misal kelompok Dahlia, kelompok Lili, kelompok Mawar, kelompok Kenanga dan kelompok Melati. Nomor yang ditunjuk guru yang akan menjawab. Guru memberikan kuis/tes kepada siswa secara individual dan setelah itu guru memulai game dengan sistelah itu guru memulai game dengan sistelah itu guru memulai games dengan sistem tournament dimana pada saat kuis tim yang mendapatkan poin terbanyak akan mendapatkan penghargaan. Pada kegiatan konfirmasi, guru memberikan kesempatan kepada siswa untuk bertanya tentang materi yang belum mereka

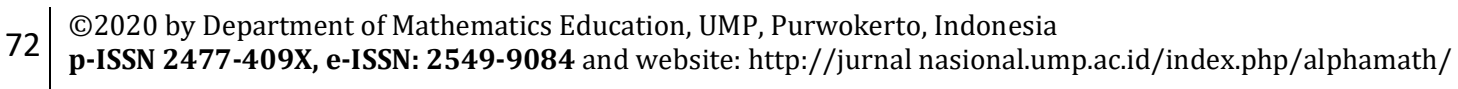


pahami. Guru memberikan penghargaan kepada kelompok melalui skor penghargaan berdasarkan perolehan nilai peningkatan hasil belajar individual dari skor dasar ke skor berikutnya setelah mereka melalui kegiatan kelompok

Berdasarkan tabel 1. dapat diketahui bahwa rata-rata persentase minat siswa tiap aspek pada pratindakan sebesar 57,7\% pada kategori rendah. Kemudian mengalami peningkatan pada siklus I menjadi 72,2\% dengan kualifikasi sedang. Namun terdapat beberapa kelemahan yang di temukan dan harus di sempurnakan, diantaranya adalah sebagai berikut.Siswa masih menemui kesulitan dalam mengerjakan tugas cenderung bertanya pada guru, peneliti, pengamat tanpa terlebih dahulu mendiskusikan dengan teman sekelompoknya. Kerjasama antar kelompok masih belum optimal, masih ada siswa yang tidak mau memberikan pendapatnya ketika diskusi kelompok berlangsung. Hasil refleksi tersebut menjadi perbaikan agar siklus 2 lebih baik pelaksanaannya. Kemudian pada siklus II rata-rata persentase hasil minat siswa mengalami peningkatan menjadi $80,2 \%$ dengan kualifikasi tinggi. Secara umum, berdasarkan minat siswa mengalami peningkatan yang signifikan setelah diterapkan model pembelajaran kooperatif tipe TGT. Hal ini senada dengan (Haryadi, Sapti, \& Nugraheni, 2014) pembelajaran matematika dengan model TGT dapat menigkatkan minat dan hasil belajar siswa kelas V SDN 1 Mranti, hal ini terlihat dari nilai rata-rata kelas tes hasil belajar siklus 1 dan 2.

Berdasarkan tabel 2. dapat diketahui adanya peningkatan rata-rata nilai hasil belajar, pada pratindakan 66,48 meningkat menjadi 71,41 pada siklus I dan pada siklus II mengalami peningkatan menjadi 79,72. Telihat juga nilai tertinggi pada pratindakan 75 meningkat menjadi 100 pada siklus I dan pada siklus II sama dengan siklus I yaitu 100. Sedangkan pada pratindakan nilai terendah 45 menurun pada siklus I yaitu 12 dan mengalami peningkatan di siklus II yaitu 22. Minat peserta didik dalam kegiatan pembelajaran meningkat pada siklus II dibandingkan pada siklus I karena proses pembelajaran mulai bervariasi setelah diterapkan model TGT. Pembelajaran yang dilakukan mulai berpusat pada peserta didik. Guru berperan sebagai pembimbing supaya terjadi pengalaman dalam belajar. Tujuan kegiatan pembelajaran tercapai kemampuan minimal peserta didik (kompetensi dasar). Pengelolaan pembelajaran lebih menekankan pada kreativitas peserta didik, meningkatkan kemampuan minimalnya, dan mencapai peserta didik yang kreatif serta mampu menguasai konsep-konsep. Guru juga melakukan pengukuran secara kontinu dalam berbagai aspek pengetahuan, sikap, dan keterampilan. Secara keseluruhan dapat terlihat siswa tuntas pada pratindakan 6 meningkat pada siklus I 14 dan mengalami peningkatan pada siklus II yaitu 16 siswa. Secara umum, berdasarkan rata-rata mengalami peningkatan yang signifikan setelah diterapkan model pembelajaran Team Games Tournament. Hal ini senada dengan (Tyas, 2015) penerapan pembelajaran kooperatif tipe Teams Game Tournament (TGT) dapat meningkatkan minat dan hasil belajar matematika pada siswa kelas V SDN 07 Sumberpucung Malang. Lebih lanjut dalam penelitian (Surya, 2018) pembelajaran dengan model pembelajaran kooperatif tipe Team Game Tournament (TGT) juga dapat meningkatkan hasil belajar Matematika siswa kelas V SD Negeri 25 Pekanbaru.

\section{Simpulan}

Berdasarkan hasil penelitian dan pembahasan yang telah dillakukan di SD Negeri Tukangan Yogyakarta dapat disimpulkan bahwa model cooperative learning tipe Team Games Tournament (TGT) dapat meningkatkan minat dan hasil belajar siswa kelas II dalam pembelajaran matematika di SDN Tukangan Yogyakarta. Pada pra tindakan minat belajar 
pada kategori rendah, pada siklus I pada kategori sedang, dan meningkat pada siklus II pada kategori tinggi. Sedangkan untuk rata-rata hasil belajar matematika pada pra tindakan 66,48 meningkat menjadi 71,41 pada siklus I dan pada siklus II mengalami peningkatan menjadi 79,72. Harapannya model cooperative learning tipe Team Games Tournament (TGT) dapat diterapkan di kelas dipadukan berbagai media pembelajaran yang variatif.

\section{Daftar Pustaka}

Aiken, L. R. (1999). Personality Assessment Methods and Practices (3rd Ed). Kirkland: Hogrefe\&Huber Publishers.

Ainley, M., Hidi, S., \& B, Dagmar. 2002. Interest, learning, and the psychological processes that mediate their relationship. Journal of Educational Psychology 2002, Vol. 94, No. 3, $545-561$.

Arifin, Z. (2012). Evaluasi Pembelajaran. Bandung: PT. Remaja Rosda.

Baharudin \& Wahyuni, E.N. (2010). Teori Belajar dan Pembelajaran.Yogyakarta: Ar-Ruzz Media.

Brookhart, A. J. N. \& S. M. (2007). Educational assessment of students. Upper Saddle River, New Jersey: Pearson Education, Inc.

Djamarah, S.B. (2008). Strategi belajar mengajar (edisi revisi). Jakarta: Rineka Cipta.

Hadi, F. R. (2017). Penerapan Model TGT (Teams Games Tournament) dalam Pembelajaran Matematika untuk Meningkatkan Hasil Belajar Siswa Kelas V SDN Taman 3 Madiun. Jurnal Bidang Pendidikan Dasar, 1(2), 26-36.

Haryadi, D., Sapti, M., \& Nugraheni, P. (2014). Peningkatan Minat dan Hasil Belajar Siswa Dengan Model Pembelajaran TGT. Jurnal EKUIVALEN - Pendidikan Matematika, 11(2), 87-90.

Huda, M. (2016). Cooperative Learning. Yogyakarta: Pustaka Pelajar.

Rhosyida, N., Muanifah, M. T., \& Trisniawati, T. (2019). Eksplorasi Minat Belajar Matematika Melalui Diary Siswa di Sekolah Dasar. Dwija Cendekia: Jurnal Riset Pedagogik, 3(2), 205-2016.

Sax, G. (1980). Principles of educational and psychological measurement and evaluation Second Edition.Wadsworth Publishing Company.

Slavin, R. E. (2006). Educational Psycology. Theory and practice eight edition. New York: Allyn and Bacon.

Susanto, A. (2013). Teori Belajar dan Pembelajaran di Sekolah Dasar. Jakarta: Kencana Prenada Media Group

Surya, Y. F. (2018). Penerapan Model Pembelajaran Kooperatif Tipe Team Gamestournament (Tgt) Untuk Meningkatkan Hasil Belajarmatematika Siswa Kelas V Sekolah Dasar Negeri 003 Bangkinang Kota. Jurnal Cendekia: Jurnal Pendidikan Matematika, 2(1), 154-163. https://doi.org/10.31004/cendekia.v2i1.41

Taylor, P., Street, M., Wt, L., Elliott, B., Oty, K., Mcarthur, J., ... Mcarthur, J. (2001). The effect of an interdisciplinary algebra/science course on students' problem solving skills, critical thinking skills and attitudes towards mathematics. International Journal of Mathematical Education in Science and Technology, 32(January 2010), 811-816. https://doi.org/10.1080/00207390110053784

Tyas, D. K. F. N. (2015). Peningkatan Minat dan Hasil Belajar Matematika Melalui Pembelajaran Kooperatif Tipe TGT pada Siswa Kelas V SDN 07 Sumberpucung Malang. Jurnal Ilmiah Matematika Dan Pembelajarannya, 1(1), 58. https://doi.org/10.1017/CBO9781107415324.004

Wilujeng, S. (2013). Peningkatan Aktivitas Dan Hasil Belajar Siswa Melalui Model Teams

$74 \mid \begin{aligned} & \text { C2020 by Department of Mathematics Education, UMP, Purwokerto, Indonesia } \\ & \text { p-ISSN 2477-409X, e-ISSN: 2549-9084 and website: http://jurnal nasional.ump.ac.id/index.php/alphamath/ }\end{aligned}$ 
Games Tournament (Tgt). Journal of Elementary Education, 2(1), 45-53

Woolfolk, A. 2007. Educational Psychology. Boston: Pearson Education. 